\title{
ARISTOTLE ON PHAINOMENAL COGNITION: ACCESSIBILITY AND EPISTEMOLOGICAL LIMITATION*
}

\author{
RAPHAEL ZILLIG \\ https:/ / orcid.org/0000-0001-6758-749X \\ Universidade Federal do Rio Grande do Sul \\ Department of Philosophy \\ Porto Alegre, RS \\ Brazil \\ rzillig@gmail.com
}

\begin{abstract}
Article info
CDD: 185

Received: 25.03.2019; Accepted: 09.09.2019

DOI: http://dx.doi.org/10.1590/0100-6045.2019.V42N4.RZ
\end{abstract}

\section{Keywords \\ Phainomena \\ Appearances \\ Research \\ Method \\ Aristotle}

\begin{abstract}
According to Aristotle, phainomena or "appearances" provide the basis from which researches proceed. This shows that in spite of phainomena often corresponding to what falsely appears to be the case, there is genuine cognition through them. In this paper, I focus on two features of phainomenal cognition: accessibility and epistemological limitation. A phainomenal
\end{abstract}

*This work has been developed with the support of $\mathrm{CNPq}-$ Conselho Nacional de Desenvolvimento Científico e Tecnológico and CAPES - Coordenação de Aperfeiçoamento de Pessoal de Nivel Superior. It benefited from discussions with Wolfgang Sattler, Inara Zanuzzi, Lucas Angioni, Breno Zuppolini, Fernando Mendonça, Hendrik Lorenz, Alfredo Storck, Manuel Berrón, Fabian Mié and Marco Zingano. I am very thankful for their comments and suggestions. I am also grateful for the useful remarks of the blind referees and editors of this volume. 
cognition of $\mathrm{x}$ is limited in the sense that there is always a stronger cognition of $\mathrm{x}$ to be attained. In this way, a research always aims at surpassing the phainomenal cognition of its subject matter. On the other hand, phainomenal cognition is always somehow accessible. Resorting to the relation between phainomena and the distinction between the more intelligible to us and the more intelligible by nature, I intend to put forward a relative (as opposed to an absolute) understanding of both accessibility and epistemological limitation of phainomena.

\section{INTRODUCTION}

For Aristotle, phainomena or "appearances" are the raw material of researches. Through them, the researcher gains a first access to the part or aspect of the world that she intends to investigate ${ }^{1}$. They provide a limited and often inaccurate grasp of reality, but ignoring them in the course of a research results in empty theories that are inadequate for their explanand $a^{2}$. In fact, Aristotle often turns to phainomena in order to ascertain the appropriateness of theories ${ }^{3}$.

These aspects of the significance of appearances for researches show that, in spite of the fact that phainomena often correspond to what appears falsely to be the case, there is genuine cognition from phainomena. Accordingly, I will say that there is a phainomenal cognition of $x$, when $x$ is grasped solely on the basis of phainomena.

1 E.g.: Prior Analytics (APr) A30, 46a17-27; De Generatione Animalium (GA) III 10, 760b27-33; II 8, 748a7-16; Eudemian Ethics (EE) I 6, 1216b26-35; Nicomachean Ethics (NE) VII 1, 1145b2-7; De Partibus Animalium (PA) I 1, 639b7-11, 640a13-15.

2 E.g.: De Caelo (DC) II 13, 293a17ff., III 7, 306a3ff.

${ }^{3}$ E.g.: EE II 11, 1228a18-19, VII 1, 1235a31, VII 2, 1235b13-18, 1236a25-26, 1236b21-23; NE VII 1, 1145b27-28. 
Phainomenal cognition has two distinctive features on which I intend to focus here: accessibility and epistemological limitation. A phainomenal cognition of $x$ is limited in the sense that there is always a stronger cognition of $x$ to be attained. In this way, a research always aims at surpassing the phainomenal cognition of its subject matter. On the other hand, phainomenal cognition is always somehow accessible. Whereas proper knowledge or understanding of $x$ is difficult to attain, phainomena are supposed to be easily grasped, which accounts for researches regularly taking a survey of the relevant phainomena as their starting point.

As through phainomena we attain in a research an accessible but limited cognition of some part or aspect of reality that is relevant to the research, phainomena play the role of what is more intelligible to us (gnôrimoteron hêmin), as opposed to what is more intelligible by nature (gnôrimoteron physei or haploss). As is well known, this distinction captures, respectively, the points of depart and arrival of an investigation ${ }^{4}$. Researches start with what is more intelligible to us and progress towards what is more intelligible by nature. At the point of depart, there is a feeble, but accessible kind of cognition (Metaphysics (Metaph.) Z 4, 1029b8-10), whereas at the end we hope to attain strict knowledge, which can only be laboriously achieved. All these features of the distinction between the more intelligible to us and the more intelligible by nature place phainomena in the role of the intelligible to us.

By focusing on the different ways in which phainomena may be accessible and epistemologically limited, I intend to put forward an articulate view of phainomenal cognition and its significance to researches. After discussing standard cases of phainomena, I will approach a non-standard case in order to make some suggestions concerning accessibility

${ }^{4}$ E.g.: Metaph. Z 4, 1029b3-12; De Anima (DA) II 2, 413a11-15. 
and epistemological limitation. Aiming at a general understanding of phainomena, I will put forward a view about these features that is broader than what could be expected exclusively on the basis of standard cases 5 .

\section{Veridical and non-veridical phainomena}

With a view to discussing the import that phainomena have in a research, it is necessary to take into account that phainomena and related terms occur in so-called veridical and non-veridical uses ${ }^{6}$. In the first of both uses, to say that $\phi$ is

5 As is widely acknowledged, Aristotle includes endoxa or "reputable opinions" in the class of phainomena. The methodological importance of endoxa, in particular in the field of practical philosophy, has been highly stressed and possibly overemphasized by some very influential pieces of literature (Owen : 1961; Barnes : 1980; Nussbaum : 1986 and Irwin : 1987 and 1988). Recently, the importance and the role of endoxa in practical philosophy has been subjected to discussion and alternative views have been put forward (see, for instance, Frede : 2012; Karboski : 2015a and 2015b and Devereux : 2015). Irrespective of the proper import of endoxa in practical philosophy, it remains true that they qualify in some way as phainomena. They in fact provide phainomenal cognition and so they are both epistemologically limited and more accessible than strict cognition. The specificities of their accessibility and epistemological limitation, however, require a discussion of its own and so I will not focus on them in this paper.

${ }^{6}$ Veridical vs. non-veridical is a distinction that applies to such words as phainomenon and phainesthai. However, I will occasionally transfer the distinction from the words to the signified items and talk of veridical and non-veridical phainomena (as opposed to veridical and non veridical uses of the term "phainomena"). Veridical phainomena are genuine displays of reality, whereas nonveridical ones are apparent but not necessarily genuine displays of some part or aspect of reality. 
a phainomenon amounts to saying that $\phi$ corresponds to some part or aspect of reality as it appears to us. So understood, $\phi$ is an appearance of some part or aspect of reality $x$ by being an actual display or manifestation of $x$. In this sense, if I experience a phainomenon of $x$, I can be truly said to have some cognition of $x^{7}$. Accordingly, Aristotle often uses ta phainomena in this sense interchangeably with $t a$ buparchonta and other terms that unequivocally refer to things as they are ${ }^{8}$.

In the non-veridical sense, on the other hand, to say that $\phi$ is a phainomenon amounts to saying only that $\phi$ is an appearance of $x$, that is $\phi$ does not necessarily correspond to a true display of $x$. In this sense, if I experience a phainomenon of $x$, I cannot be certainly said to have some cognition of $x^{9}$.

The non-veridical use may be non-committal and in some occasions it may imply uncertainty ${ }^{10}$. However, it may

${ }^{7}$ E.g.: $D C$ II 14, 297a2-6; GA I 20, 729a31-32, III 6, 756b23-24.

8 E.g.: Meteorologica (Meteor.) II 1, 315b17; APr A30, 46a23, 25; Posterior Analytics (APo) A19, 81b23.

${ }^{9}$ As has been often noted by interpreters, each of both senses of phainomenon is related to one of two uses of the verb phainesthai. The veridical sense is related to the uses of phainesthai in which it takes a participle as its complement. In such cases, phainesthai can usually be translated as "is manifestly so". The non-veridical sense of phainomenon, on the other hand, is related to the uses of phainesthai when it takes an infinitive as its complement. In these cases, phainesthai is often translated as "it seems to be so" and similar expressions. It is important to stress, though, that these typical uses of the verb allow for exceptions. See Bonitz 808b37 ff.; Barnes : 1980, p. 491, n. 1; Shields : 2013, p. 10-12.

${ }^{10}$ In this way, Aristotle says that "we do not say that this appears [phainetai] to us to be a man whenever we are in a state of actuality accurately in relation to the perceptual object, but rather 
also be used in a distinctly negative sense. In those cases, it is associated to what falsely appears to be so and so and is often used to refer to illusions and even forgeries ${ }^{11}$.

Doubts often arise as to some particular phainomenon being a genuine or a false display of some aspect of reality. Establishing criteria for deciding which is the case in a specific situation is, of course, a pressing matter for the researcher. At least regarding basic kinds of empirical phainomena, Aristotle seems to rely on the idea that in normal cases we are prone to grasp the truth and so have veridical phainomena. In those cases, it is expected (if not assured) that a subject adequately exposed to $x$ will have a genuine grasp of $x$ through veridical phainomena. I will therefore define normal cases as the cases in which $x$ stands in relation to subject $s$ so that it can display itself to $s$ appropriately. Accordingly, if the adequate conditions for $x$ to manifest itself are given, we should have veridical phainomena of $x$.

Aristotle's stance to that regard somehow harmonizes with ordinary intuitions. In a great deal of cases, we ordinarily understand that the capacity of some appearance to be taken as a display of some $x$ is not actualized on account of its failing to conform to normality. When I press my eye with my finger, a single object appears to be two instead of one (Metaph. K4, 1063a6-10). I acknowledge that there is some capacity in the appearance to be taken as a display of reality, as it does appear as though there were two objects instead of one before me. This capacity however is immediately barred from being actualized because I know that the appearance is just the result of my

whenever we do not perceive clearly whether it is true or false." (DA III 3, 428a12-15, Shields' translation).

11 E.g.: NE III 4, 1113a23-24; Topics (Top.) I 1, 100b23-25; Sophistici Elenchi (Soph. El.) 1, 164b19-27, 165a17-24; 2, 165b7; 3, 165b17; Meteor. II 9, 370a12; Physics (Phys.) VIII 10, $267 a 14$. 
provoking a distortion in the way my eye works and is therefore not in the range of normal cases.

As a philosopher and a scientist, however, Aristotle would be expected to provide fully developed criteria for what counts as normal cases relating to appearances. This he never does systematically, and his treatment of the issue probably allows for a considerable grey area between normality and abnormality. However, he does put forward some criteria that apply to the kind of cases we are considering, that is, cases in which phainomena are directly related to sense-perception. These criteria include evaluating whether $\phi$ stems from senses being applied to their proper objects and whether it stems from senses that are working under their appropriate conditions. ${ }^{12}$ In this way, we should not trust the appearance of sweetness of a fruit, if it comes about from the brightness and colours of its skin. The sense of view has not taste as its proper object and among perceptual appearances, only those associated with the sense of taste would be authoritative enough. In a similar way, the appearance of tower A being smaller than tower B is not to be trusted if one or both towers are seen at a long distance. Visual appearances are not authoritative when the object is seen from afar. Accordingly, in the same way as we reject as unreliable the appearances stemming from the eye-pressing experiment on account of its nonconformity to normality, so we disregard appearances of magnitudes and colours when seen at distance and of flavours when the sense of taste is altered by illness or otherwise. ${ }^{13}$

In this way, we get a picture according to which there are criteria for discerning normal cases as regards perceptual phainomena and according to which normal cases

${ }_{12}$ Metaph. Г5, 1010b3-26; Parva Naturalia (PN), 460b20-22.

${ }^{13}$ Metaph. Г5, 1010b2-10; K4, 1062b36-1063a10; PN, 448b12-15. 
provide veridical phainomena. This picture is grounded on the fundamental assumption of generosity or benevolence of nature. According to this assumption, nature does nothing in vain and always does what is the best among all possible alternatives ${ }^{14}$. Now, we are evidently equipped with cognitive capacities for grasping the world around us. If we were to fail in grasping reality even in those cases that conform to the optimal use of our basic cognitive apparatus, there would be no reason for us to be endowed as we are with our cognitive capacities. In that case, the assumption of benevolence of nature would have to be rejected.

These basic assumptions are at the backdrop of Aristotle's rejection of two views that do away with the distinction between veridical and non-veridical phainomena. Some thinkers, as the Protagorean, have completely collapsed the non-veridical into the veridical sense of phainomena and have adopted the view that all appearances are true ${ }^{15}$. To the Protagorean, the coldness experienced by the feverish corresponds to the truth as much as the warmness experienced by the healthy. Others, as the Eleatic, rejected as illusions such appearances as those according to which there is movement and plurality (Phys. I $2-3)$. This of course leaves scant room if any for the notion of veridical phainomena.

Now, there is no way to uphold the assumption of nature's benevolence if the way reality appears to us is

${ }^{14}$ For the thesis according to which nature does nothing in vain, see, among many others, DC I 4, 271a33, II 11, 291b13-14; DA III 9, 432b21-22; for the thesis that nature always does what is the best among the possible alternatives, see (also among other passages), Phys. VIII 7, 260b22-23; 6, 259a10-12; De Generatione et Corruptione (GC) II 10, 336b27-28; DC II 5, 288a2-3; PN, 469a2829.

${ }^{15}$ Metaph. Г5, 1009a6-15; see also DA III 3, 427b3. 
systematically misleading as it is according to the Eleatic argument. If plurality and movement are illusions, then hardly any appearance is trustworthy. In that case, nature has vainly endowed us with a cognitive apparatus for grasping appearances and has constituted us so as to be systematically in error. On the other hand, if all appearances are true, then reality is contradictory ${ }^{16}$, which also does away with the assumption of nature's benevolence. If reality is incompatible with the most basic principle according to which we think and talk, then the conclusion that we have been vainly endowed with capacities that are systematically unable to grasp the world will force itself upon us again.

\section{Sense-perception and experience}

Veridical phainomena are grasped when our relevant cognitive capacities operate in normal circumstances. In those cases, when we are exposed to $x, x$ is manifest to us and we have a genuine cognition of $x$. This makes it only reasonable that we should start an investigation by gathering all available phainomena related to the subjectmatter. However, so far we have considered only a very restricted kind of phainomenon. As noted, when engaged in the refusal of the view that all appearances are true, Aristotle resorts to the fact that senses are reliable when applied to their proper objects. This is naturally taken as a reference to the doctrine according to which special perceptibles are immune to error or liable to it in the smallest degree. ${ }^{17}$ According to this view sensations as

16 Metaph. Г5, 1009a6-15; K6, 1062b12-19.

17 See $D A$ III 3, 427b12, 428b18-19; see also $D A$ II 6, 418a12, 15-16; PN, 448b8-10. 
those of colour, sound, flavour and similar, which are exclusive of a single sense, should be the most trustworthy. This sets them in contrast to the so called common perceptibles, that is such appearances as those of motion, rest, number, shape and magnitude, which can be perceived by all senses or at least by more than one ${ }^{18}$. Common perceptibles are much more prone to error than special perceptibles.

The highly reliable character of special perceptibles may, indeed, play a role in the argument against those that, in one way or another, wipe out the distinction between veridical and non-veridical phainomena. It provides a clear case for the thesis that there are criteria for identifying reliable appearances. However, the existence of veridical phainomena should make us confident that appearances are the appropriate starting point of scientific inquiry, which is a role that special perceptibles alone cannot play. In whatever way they are understood, special perceptibles are too limited as to the kind of things they are displays of, so that they cannot provide the basis for the researcher to progress towards a scientific grasp of reality ${ }^{19}$.

In fact, the results of perception alone, even when it is not restricted to the limited range of special perceptibles, are too narrow to provide a basis for science. By itself perception is limited to particulars ${ }^{20}$, whereas the basis for progress in research requires phainomena of a universal kind. That is the case of those appearances that are stock

${ }^{18} D A$ II 6, 418a16-20; DA III 1, 425a16; PN, 442b5-7.

${ }^{19}$ For criticism to the suggestion that Aristotle tries to ground reliability in phainomena to the immunity to error of special perceptibles, see Bolton : 2009.

${ }^{20}$ And for some $x$ to be grasped as a temporally extended item, perception must be assisted by other faculties such as memory and phantasia (APo B19, 99b34-35; Metaph. A1, 980a27-b28). 
examples for the starting point of investigation, namely thunder taken as noise in the clouds and eclipse taken as privation of light. In fact, when referring to perception as a provider of phainomena, Aristotle does not has in view the particular items which are grasped by perceptive capacities alone. This can be seen from the following examples of phainomena that can be related to perception:

All of the so-called elements change into each other (DC III 7, 306a3-6: phainetai kata tên aisthêsin).

Animals are not male or female on account of the whole of their bodies, but of specific bodily parts (GA I 2, 716a27-31: hoper kai phainetai kata tên aisthêsin).

Animals are moist and warm and life is of that nature, whereas old age is dry and cold and so is a corpse (PN, 466a20: phainetai gar houtôs).

The air which is breathed out is hot, whereas that which is breathed in is cold ( $P N, 472 \mathrm{~b} 35$ : phainetai gar).

The heart is immediately filled with blood, being the first of the bodily parts to be formed (PA III 4, 666a10: ek tôn anatomôn de katadêla $)^{21}$.

21 This passage does not contain an explicit reference to phainomena. However, it displays a general fact that is manifest (katadelos) on the basis of observation by dissection. In this way, the passage presents a phainomenon of the same kind as those that are recorded in the previous quotations, even if it does not mention such terms as phainesthai and phainomenon. 
To these cases many others could be added in support of the same point. Far from relating to special perceptibles, these examples relate rather to a general experience of highly regular sorts of events. In fact, phainomena kata tên aisthêsin, that is, perception-related phainomena are more appropriately understood as the product of empeiria or experience than directly of perception. Empeiria is the result of recurrent perception of the same kind of objects and events and it arises through the activity of memory 22 .

Aristotle holds that the same part or aspect of reality $x$ can be grasped through strict knowledge and through empeiria. Through the latter we have knowledge of the hoti, that is, we know that $x$ is the case, whereas through the former we have knowledge of the dioti, that is, of the cause or explanation of why $x$ is as it is ${ }^{23}$. These two kinds of knowledge are, in fact, linked to each other as two stages in the progress to the attainment of proper knowledge. Establishing the hot $i$ is a condition for seeking the dioti. We first know that $x$ is the case and then proceed to explain why it is $\mathbf{s o}^{24}$. The suggestion here is that empeiria is a provider of the hoti, that is, the explananda for scientific knowledge through what has been called phainomena kata tên aisthêsin.

22 Metaph. A1, 980b28-981a1; APo B19, 100a3-6.

23 "we think that knowledge and understanding belong to art rather than to experience, and we suppose artists to be wiser than men of experience $(. .$.$) ; and this because the former know the$ cause, but the latter do not. For men of experience know that the thing is so [to hoti], but do not know why, while the others know the 'why' [to dioti] and the cause" (Metaph. A1, 981a24-30, Ross' translation). In this passage, the point is made by reference to art (technê) and not science (epistêmê). Art and science, however, are being jointly contrasted to empeiria and the point made in the passage applies to both.

${ }^{24}$ E.g.: APo B1, 89b30; Metaph. Z 17, 1041a15-20. 
A difficulty for this suggestion lies in the fact that when comparing empeiria to science and art, Aristotle relates the former to knowledge of particulars and the latter to knowledge of universals (Metaph. A1, 981a5-12; 981a15$24)^{25}$. Science, however, deals with general and not with particular facts, as only regular states of affairs can be said to have causes in the sense that is relevant for science. In fact, in APo B2, 89b37 seeking the hoti is associated with seeking whether there is a middle term, whereas seeking the dioti is associated with seeking what the middle term is. This implies that knowing the boti amounts to recognizing a state

25 In different ways, influential interpretations have drawn on such passages to downgrade the relation of empeiria with knowledge of universals. See, for instance, Ross: "An animal or a man possessing only empeiria (...) is unconsciously affected by the identical element in the different objects. But in man a new activity sometimes occurs, which never occurs in the lower animals. A man may grasp the universal of which Callias and Socrates are instances, and may give to a third patient the remedy which helped them, knowing that he is doing so because the third patient shares their general character. This is art or science." (1924, v. I, p. 116). As can be seen in the above quotation, Ross attributes to empeiria only an unconscious grasp of universals, whereas identifying a general trace of several particulars is seen as belonging already to science. In a similar vein, McKirahan holds that people with empeiria "have not consciously marked off the individuals into a class, cannot 'put their finger' on the common element (the class concept)" (1992, p. 242, emphasis in the original). Bolton, by contrast, weakens in another way the association of empeiria with knowledge of universals. While he does associate empeiria with a kind of universal knowledge, he stresses that it is a kind of knowledge that is "jumbled up" and does not allow for a precise distinction between the items that fall and those that do not fall under the universal (1991, p. 3-7). For a comprehensive appraisal of various interpretations of the way in which empeiria relates with, respectively, particulars and universals, see Hasper and Yurdin : 2014, p. 126 ff. 
of affairs as belonging to a natural kind that is liable to scientific explanation.

In spite of Aristotle's occasional indications to the contrary, there is extensive textual evidence to support the inclusion of knowledge of universal facts of the form "All Fs are G" under the scope of empeiria 26 . In fact, even if some special knowledge of universals is restricted to science, it seems clear that the product of empeiria is already in some sense universal. In medical matters, experienced people may be more effective in providing treatment for different kinds of individuals than those who have science without empeiria (Metaph. A1, 981a12-15) ${ }^{27}$. In order to select the appropriate treatment, the experienced agent has to correctly identify connections between kinds of treatments and kinds of patients (for instance, the phlegmatic and the bilious), which implies being able to recognize general patterns. Empeiria, therefore, involves some grasp of universals.

As Hasper and Yurdin (2014) have argued, it is possible to associate empeiria with proper knowledge of logically universal facts by interpreting the universal knowledge that is restricted to science in light of $A P o \mathrm{~A} 4,73 \mathrm{~b} 26-32^{28}$. This

${ }^{26}$ The point is made by Hasper and Yurdin (2014). They argue that empeiria is knowledge of "general facts", which are defined as "facts of the form 'Fs are G' - whether all Fs, some, many, or none." (2014, p. 120). As they note, "the class of general facts (...) includes logically universal facts — facts of the form "All Fs are G' - but is not limited to them." (ibid). They provide extensive textual evidence for the claim that empeiria is knowledge of general facts (including universal facts) in pages 120-126.

${ }^{27}$ See also NE VI 7, 1141b14-21.

28 "I call universal what holds of every case and in itself and as such. It is clear, then, that whatever is universal holds of its objects from necessity (to hold of something in itself and to hold of it as such are the same thing: e.g. point and straight hold of 
passage introduces a sense of universal that applies exclusively to "what holds of every case and in itself and as such" (73b26-27, Barnes' translation). According to this suggestion, science is not knowledge of universals understood simply as "that which is by its nature predicated of a number of things" (De Interpretatione (De Int.) 7, 17b39, Ackrill's translation). To have scientific knowledge of a universal fact does not amount simply to knowing that all Fs are $G$, but to knowing that the connection between $F$ and $G$ holds because of $F$ in itself (Hasper and Yurdin : 2014, p. 131) 29 . This associates scientific knowledge of universals with knowledge of the causes or explanations, as in the model of the Posterior Analytics to have explanatory knowledge that $G$ holds of $F$ amounts to knowing that $G$ holds of $\mathrm{F}$ in itself.

Empeiria, therefore embraces proper knowledge of logically universal facts in the sense that it includes knowledge of the form "all Fs are G" 30 . In this way, experienced agents are able to grasp, for instance, that all patients with yellowish skin-colour benefit from such and such a medicine when they have a fever. What they lack is knowledge of the fact that the benefit of the medicine holds of yellow-skinned patients, i.e. bilious patients, in virtue of their being bilious. In other words, they do not know that the effects of the medicine result from its interaction with the bodily factor that accounts for the

lines in themselves - for they hold of them as lines; and two right angles hold of triangles as triangles - for triangles are in themselves equal to two right angles" (Barnes' translation).

${ }^{29}$ See also the contrast between those who know universally and those who know in a sophistical way: APo A5, 74a25-32.

30 This kind of knowledge does not have to be either unconscious or confused, as implied by the influential interpretations mentioned above. 
patients being bilious, namely, a certain disposition of the liver. This corresponds to their ignoring the cause in virtue of which $G$ holds of $F$ - a kind of knowledge that is restricted to art and science.

As noted, possession of this kind of non-scientific universal knowledge is a condition for experienced agents to be effective in action. Another condition is the capacity of correctly identifying particulars as instances of universals. Beyond knowing that yellow-skinned patients benefit from such and such a medicine, experienced agents must be able to recognize Callias' skin-colour as conforming to the appropriate shade of yellow. Otherwise, their knowledge would not be efficient, as it would not be appropriately translated into the treatment of particular patients. This ability to correctly place a particular situation or object under a general pattern requires acquaintance with particulars and may be all that Aristotle has in mind when he stresses the connection of empeiria with particulars ${ }^{31}$.

On the basis of this understanding of empeiria it is possible to associate it with the kind of universal phainomena that provides the hoti for scientific explanation. Nothing, therefore, prevents empeiria to be the source of phainomena kata tên aisthêsin.

As has been seen, this kind of phainomena is at some distance from those for which a sketch for the criteria of reliability has been provided around the notion of normality. However, for Aristotle's trust on our natural tendency to grasp the truth to have some effect over strong kinds of knowledge such as science or understanding, he has to make sure that the relevant sort of phainomena is at least almost as reliable as the strictly perceptual sort. It is to be expected, then, that the notion of normality should work

31 As Hasper and Yurdin put it, "experience is knowledge of general facts, consisting in recognitional and practical abilities to detect and act on particulars of the relevant sorts" (2014, p. 147). 
in the case of experience in a similar way as it does in the case of strict perception of particulars. In normal cases, our experience of highly regular items such as natural species and the related states of affairs should produce veridical phainomena. When such items as the bilious and the fact that bilious people benefit from such and such a medicine stand in relation to a subject $s$ so that they can manifest themselves appropriately, $s$ should have a genuine, albeit limited grasp of them through veridical phainomena.

Aristotle is even less clear regarding the criteria for what counts as normality in experience than he is in the case of strict perception. It is however plausible that these criteria should rely on the regularity and coherence of the appearances from which experience arises through perception and memory. In any case, in experience as in perception normal cases are expected (if not assured) to produce veridical phainomena. As a matter of fact, the thesis that nature does nothing in vain and always chooses the best among the available alternatives leads us to expect that in normal conditions not only sense-perception, but also experience is trustworthy. It would be difficult to uphold the view that nature does nothing in vain if we could not trust beliefs that naturally emerge from our constant observation of highly regular events, such as the belief according to which spring always follows winter and is followed by summer. If we could not trust our inclination to conclude from the high regularity of seasonal events that the proper place of spring in the year cycle is between winter and summer, nature would again have endowed us with useless capacities.

Phainomena, argument and explanation

Up to this point all phainomena I have been considering are in one way or another related to our receptive cognitive 
capacities. So far, phainomenal cognition has been understood under the conditions for the world to show itself to us either through perception or experience. In fact, Aristotle often talks of phainomena as things that are out there to be gathered. They are usually treated as something that is observed or somehow handed down to us and not produced or put forward as a theory or a hypothesis. Accordingly, Aristotle frequently opposes phainomena to arguments and theories $(\log 0 \imath)^{32}$ and many unreliable perception-related phainomena are disproven by way of arguments. For instance, to the sight the sun appears as being one foot in diameter ${ }^{33}$, but we know on the basis of demonstrations done in astronomical studies that it is greater than the earth (Meteor. I 8, 345b1-3).

This contrast is understandable on the basis of the fact that phainomena are commonly associated with the hoti for researches. It belongs to our receptive capacities to identify what is in need of explanation and to our active, intellectual ones to provide the explanation or the dioti. This contrast is usually noted by interpreters ${ }^{34}$ and, as the examples just given show, it is appropriately applied in several particular cases. There is however a risk of overemphasizing the contrast, as one might be tempted to conclude that phainomena are intrinsically opposed to the results of arguments and are intrinsically associated with the boti. This is not the case, as some explanatory conclusions drawn from highly speculative arguments are put forward by

32 E.g.: DC II 13, 293a23-27; GC I 8, 325a23-28; EE I 6, 1217a10-16; PN, 468a20-23, 469a23-b1.

${ }_{33}$ DA III 3, 428b2-4; PN, 458b28-29, 460b18-27.

34 "To call something a phainomenon is to contrast it, in a particular context at least, with the conclusion of an argument. (...) Talk of appearances suggest immediacy, in contrast to the belief we form after further reflection and argument." (Irwin : 1987, p. 113). 
Aristotle in the guise of phainomena. In those cases, phainomena are unrelated to perception and provide the dioti and not the hoti of the investigation ${ }^{35}$.

This can be seen in some passages of the De Caelo. When approaching problems that pertain facts from which we are at a great distance and have little to start with (DC II 12, 292a15-16), Aristotle classes the solutions he puts forward as phainomena (II 12, 291b25; II 5, 287b35). So understood, they are opposed to more accurate solutions and are associated with merely human conviction ${ }^{36}$. In fact, they are said to provide a limited solution to the problem (mikra euporia - II 12, 291b27).

To grasp the nature of this kind of phainomenon, it will be enough to have a look at one of those problems. In DC II 5, Aristotle discusses why heaven as a whole moves to one direction instead of moving to the other. The solution provided takes stock of a series of theoretical assumptions. Aristotle starts by stating $a$ ) that nothing that is eternal is subject to chance or spontaneity (287b24-25) and b) that both heaven and its circular motion are eternal (287b26), which implies that neither is the result of chance nor spontaneity. The appropriate phainomenon-solution, then, is put forward on the basis of the assumptions $c$ ) that nature

35 Lucas Angioni, with whom I have discussed the issue on several occasions, stresses that some occurrences of phainomena refer to explanatory accounts and not to facts to be explained (see, for instance, Angioni : 2010, p. 232 and 2017, p. 225). In a similar direction, Karbowski (2015b, p. 209-210) holds that some phainomena have a role in supporting premises of arguments. On the issue, see also Falcon : 2005, p. 97-101.

36 ou mên dikaion ge pasin homoiôs epitiman, all'boran dei tên aitian tou legein tis estin, eti, de pôs echôn tô(i) pisteuein, poteron anthrôpinôs $\hat{e}$ karterôteron. tas men oun akribesteras anankas, hotan tis epituchê(i), tote charin echei dei tois euriskousi, nun de to phainomenon brêteon (DC II 5, 287b31-288a2). 
always does what is best (288a2-3) and that d) moving forward is better than moving backward (288a3-6) ${ }^{37}$. Accordingly, the motion of heaven takes the direction it takes because that is the forward direction and moving forward is better than moving backward - a result which is presented in terms of a phainomenon.

This sort of phainomenon is clearly the result of an argument that is totally based on the theoretical assumptions $a$ )-d). It evidently cannot be understood as an accessible cognition in the way that is associated with perception or experience. Imperfect as it may be, it is a fairly laborious grasp of the subject. Why then is this solution a phainomenon?

One could try to answer this question by distancing oneself from the veridical use according to which phainomena are genuine (albeit limited) cognitions. This could be done by drawing on the uses of phainesthai that express uncertainty rather than truth or falsehood ${ }^{38}$. According to this suggestion, by labelling the proposed solution a phainomenon, Aristotle would be highlighting its tentative aspect. The solution would be presented as what seems to be the case to the researcher considering the available evidence. In this way, by featuring the solution as a phainomenon, Aristotle would be underlining its provisional character.

Now, the term phainomenon certainly indicates that the solution falls short of a complete and proper scientific answer to the problem. To that regard, it does suggest tentativeness. However, I believe that it would be wrong to take this as the main reason for Aristotle's resorting to the term in this case. In particular, I do not think that it is

37 Aristotle takes the front to be more honourable than the back: PA III 4, 665b18-21.

38 As in DA III 3, 428a12-15. 
appropriate to disconnect this use of phainomenon from the veridical use that is regularly found in the context of research $^{39}$. Even if tentativeness is implied as the solution is said to be a phainomenon, other nuances of the notion in its research-related uses are also in place. In the sense that is most relevant to research, a phainomenon is a cognition, albeit an imperfect one, of the subject-matter. I believe that this aspect of the notion should not be lost from sight when the use of phainomenon in the concerned passages is considered.

As to that, it is worth stressing how much of the phainomenon-solution is not merely tentative. Assumptions a)d) are not simply guesses nor are they ad hoc hypotheses that would have been put forward in an attempt to a minimally plausible account for the matter. On the contrary, they are bona fide Aristotelian theses that bear direct relation to the subject ${ }^{40}$. In fact, Aristotle cannot reject any of $a$ )- $d$ ) without paying a considerable price for his theoretical framework as to motion and nature. On the other hand, he would hardly be able to put forward a radically different solution to the problem without rejecting or revising at least some of $a$ )-d $d$. In this way, the fact that the solution is tentative should not be understood as its being completely hypothetical. In fact, I do not think that anything in the solution would be open to rejection on the basis of further results of inquiry ${ }^{41}$.

39 This happens, for instance, when Stocks (1922) translates phainomenon in the concerned passage as "probable solution". Stocks refers to Bonitz 809a24 for similar cases. I do not think, however, that the passages listed by Bonitz offer considerable support for Stock's translation.

40 This is noted by Angioni (2010, p. 327).

${ }^{41}$ Commenting on the De Caelo's passage, Falcon notes that the proposed solution "is not a provisional account that will be, sooner or later, replaced by a genuine explanation.” (2005, p. 98) 
This, however, reissues the question as to why the proposed solution is not simply a logos instead of a phainomenon. If uncertainty is not what is being signalled by the term phainomenon, what is Aristotle's intention in using it to characterize the solution? To answer this question, I would like to resume the main traces of the kind of cognition that can be associated with phainomena. A phainomenal cognition $\phi$ of $x$ is accessible and limited in the sense that there is (at least conceivably) a stronger and less accessible cognition of $x$ than $\phi$. I want to suggest that the solution to the De Caelo's problem is a phainomenon because it is a genuine but imperfect cognition that satisfies the conditions of accessibility and epistemological limitation. Without rejecting the inaccurate character of the solution, this suggestion allows it to be taken as a true grasp of the explanatory state of affairs that it intends to portray. However, for this suggestion to work and for the solution to be seen as a phainomenal cognition, the features of accessibility and epistemological limitation of phainomena will have to be understood more broadly than they usually are when applied to standard cases.

To begin with, Aristotle's solution can be said to satisfy the condition of accessibility in the sense that it is the appropriate solution so far as it is accessible to us. Aristotle

and that it "is not what looks plausible to Aristotle as opposed to what may look plausible to other people" (2005, p. 99), but is the result of Aristotle's "genuine effort to supply an account which is as objective as possible." (ibid.). These comments, I think, highlight central features of the solution. They are not, however, appropriately captured by Falcon's rendering of the phainomenal character of the explanation in terms of "what appears to be the explanation" (2005, p. 98), which overemphasizes the tentative aspect of the solution and hints at uncertainty (in a way that is similar to Stock's "probable solution). This rendering downplays the cognitive features of the solution which are stressed in Falcon's comments. 
acknowledges that a fully adequate explanation to the problem should be in place, but it cannot be reached due to lack of evidence. The solution that can be attained from the available evidence provides the general traces of the adequate explanation, but misses its details. In that case, it is the solution so far as it can be grasped.

If that is the correct understanding of the accessibility of the phainomenon found in the De Caelo, then being accessible as a phainomenon does not necessarily mean being accessible through our receptive capacities. In that case, phainomenal accessibility should not always be understood according to the standard of the most usual examples of phainomena. It is worth remarking that this suggestion turns accessibility into a somewhat relative notion. According to the proposed interpretation, a cognitive state $x$ is accessible by being more easily attained than some other cognitive state $y$. It is not necessarily accessible in all regards and under all conditions, as perception can be said to be.

As regards epistemological limitation, Aristotle's solution can be said to be limited in the sense that it is general and due to lack of evidence, does not take into account specific features of the constitution of heaven that would play a role in a fully accurate explanation of the matter. It leaves much to be clarified, as we are left in the dark concerning the details of the inner working of heaven that result in its moving to this direction to which it has to move, as it is the best one. This means that in spite of its being factually the best attainable explanation, it is not the best conceivable explanation. It is limited in relation to the standard Aristotle sets as to what counts as a fully appropriate explanation. With this, not only accessibility, but also epistemological limitation is understood in a nonabsolute manner and in relation to what is conceived as being fully satisfactory from an epistemological point of view. 
Now I want to note the consequences that the relative/absolute distinction can have on the relation between phainomena and the intelligible to us. Research is a progress from what is intelligible to us to what is intelligible by nature. This progress constitutes a succession of progressively more accurate grasps of the subject. We can then talk of a succession $\Sigma$ of cognitive states with $n$ members, so that $c_{n}$ will be the final cognitive state, the one that corresponds to strict knowledge of the subject, whereas $c_{0}$ will be the initial, most accessible and most limited kind of cognition. $C_{0}$ is plainly and simply intelligible to us, whereas $c_{n}$ is plainly and simply intelligible by nature. However, each one of the intermediate members of the succession can be taken to be intelligible to us in one regard and intelligible by nature in another. Any intermediate member of $\Sigma c_{i}$ (such that $i$ is greater than 0 and smaller than $n$ ) is more intelligible by nature than its predecessor $c_{i-1}$ and more intelligible to us than its successor $c_{i+1}$. As there is (if not factually, at least conceivably) a more accurate grasp of the reason why heaven moves as it does, Aristotle's solution can be taken to be intelligible to us. The excessively general character of the solution as an explanation also squares well with some of Aristotle's remarks on what is intelligible to us. In fact, this notion is explicitly applied in Physics I 1 to forms of cognition that are of the nature of indistinct wholes as opposed to accounts that appropriately discriminate all relevant specific explanatory factors ${ }^{42}$.

42 "The natural course is to proceed from what is clearer and more intelligible [gnôrimôterôn] to us, to what is more intelligible and clear by nature; for the two are not the same. Hence we must start with things which are less clear by nature, but clearer to us, and move on to things which are by nature clearer and more knowable. The things which are in the first instance clear and plain to us are rather those which are compounded [ta sunkecbumena]. It is only later, through an analysis of these, that we 
I want to suggest that the relation between what is intelligible to us and phainomena is narrower than might be supposed. As each intermediate member of $\Sigma$ is more accessible and epistemologically less accurate then its successor, I see no reason not to take it as a phainomenon. If that is the case, everything that is to some extent intelligible to us is by the same token also in some regard a phainomenon. With that, both notions as defined in the previous paragraphs turn out to be coextensive.

According to this suggestion, the fact that the more intelligible to us and the more intelligible by nature form a progression of successive steps and the equation of phainomena with the more intelligible to us show that phainomena itself is a somewhat relative notion. Epistemological limitation and accessibility are the marks of phainomena. In this way, the cognitive state $c_{0}$ that is at the beginning of a research is an absolute phainomenon, as there is no kind of cognition in the progression that is epistemologically more limited than $c_{0}$ and also no cognition that is more accessible than it. On the other hand, the cognitive state $c_{n}$ that is at the end of a research is in no way

come to know elements and principles. That is why we should proceed from the universal [ton katholou] to the particular [ta kath'bekasta]. It is the whole which is more knowable by perception, and the universal is a sort of a whole: it embraces many things as parts. Words stand in a somewhat similar relationship to accounts. A word like 'circle' indicates a whole indiscriminately whereas the definition of a circle divides it into particulars [ta kath'bekasta]. And little children at first call all men fathers and all women mothers, only later coming to discriminate each of them." (Phys. I 1, 184a16-b14 Charlton's translation with alterations). On this very significant passage, see Charlton : [1970] 1992, p. 51-52; Konstan : 1975; Mansion : 1979, p. 165 ff.; Bolton : 1991; Angioni : 2001; Lesher : 2010. 
a phainomenon, for there is no cognitive state in the progression that is epistemologically less limited than $c_{n}$ or less accessible than it.

As perception and the statement of the hoti typically occupy position $c_{0}$ in a research progression, it is natural for them to provide paradigmatic examples both of phainomena and of what is intelligible to us. In fact, no kind of cognition is more accessible and epistemologically limited than a perceptive assessment of the hoti. This also explains why logoi, with their usual association with dioti are so often contrasted with phainomena. They are always more laborious than the paradigmatic cases from perception and experience. However, as I suggested, in each of the intermediary stages of the research there is a kind of cognition that is more accessible and epistemologically more limited than its successors. Therefore, the kinds of cognition that occupy intermediary positions in the progression of the research are relatively accessible and limited, if not absolutely so (as is perception). This allows for the dioti as well as the results of arguments to be phainomena, inasmuch as they may be relatively accessible and limited in the context of a certain research.

\section{REFERENCES}

ACKriLl, J. C. 1963. Aristotle's Categories and De Interpretatione. Oxford: Oxford University Press.

Allan, D. J. 1936. Aristotelis - De Caelo. (DC) Oxford: Clarendon.

ANGIONI, L. 2001. "Explanation and Definition in Physics 1.1". Apeiron, 34, pp. 307-320. 
2010. "Aristóteles e o progresso da investigação científica : o caso do De Caelo". Scientiae Studia, v. 8, n. 3, pp. 319-338.

2017. "Explanation and method in the Eudemian Ethics". Archai, 20, pp. 191-229.

BARNES, J. 1980. "Aristotle and the methods of ethics". Revue Internationale de Philosophie, 34, pp. 490-511.

_ [1975] 1993. Posterior Analytics. 2 ed. Oxford: Clarendon Press.

BEKKER, I. 1831. Peri Zôiôn Moriôn. (PA) Berlin: Reimer.

Bolton, R. 1991. "Aristotle's method in natural science: Physics I.” In: L. Judson (ed.), pp. 1-29. 2009. "Two Standards for Inquiry in Aristotle's De Caelo". In A. C. Bowen and C. Wildberg (eds.), pp. 51-82.

BonitZ, H. [1870] 1961. Index Aristotelicus. 2. ed. Berlin: Walter de Gruyter.

Bowen, A. C.; Wildberg, C. 2009. New Perspectives on Aristotle's De Caelo. Leiden: Brill.

Bywater, I. 1894. Aristotelis - Ethica Nicomachea. (NE) Oxford: Clarendon.

Charlton, W. [1970] 1992. Aristotle Physics Books I and II. Oxford: Clarendon.

Devereux, D. 2015. "Scientific and ethical methods in Aristotle's Eudemian and Nicomachean Ethics." In D. Henry, D and K. M. Nielsen (eds.), pp. 130-147.

DrossaArt Lulofs, H. J. 1965. Aristotelis de generatione animalium. $(G A)$ Oxford: Clarendon.

FALCON, A. 2005. Aristotle and the science of nature. Cambridge, Cambridge U. P. 
FESER, E. 2013. Aristotle on Method and Metaphysics. Houndmills, Palgrave Macmillan.

FOBES, F. H. 1919. Aristotelis meteorologicorum libri quattuor. (Meteor.) Cambridge: Harvard U. P.

FREDE, D. 2012. "The endoxon mystique: what endoxa are and what they are not". Oxford Studies in Ancient Philosophy, vol. 43, pp. 185-215.

HASPER, P. S.; YURDIN, J. 2014. "Between perception and scientific knowledge: Aristotle's account of experience." Oxford Studies in Ancient Philosophy, vol. 47, pp. 119-150.

Henry, D., Nielsen, K. M. 2015. Bridging the gap between Aristotle's science and ethics. Cambridge: Cambridge U. P.

InWOOD, B.; WoOLF, R. 2013. Aristotle: Eudemian Ethics. Cambridge U. P.

IRWIN, T. 1987. "Ways to first principles: Aristotle's methods of discovery". Philosophical Topics, v. XV, n. 2, pp. 109-134. 1988. Aristotle's first principles. Oxford: Clarendon.

JOACHIM, H. H. 1926. Aristotle on Coming-to-be and Passing Away. (GC) Oxford: Clarendon.

Judson, L. 1991. Aristotle's Physics: A collection of essays. Oxford, Clarendon.

KARBOWSKI, J. 2015a. "Endoxa, facts, and the starting points of the Nicomachean Ethics". In D. Henry, D and K. M. Nielsen (eds.), pp. 113-129. 2015b. "Phainomena as Witnesses and Examples: The Methodology of Eudemian Ethics 1.6." Oxford Studies in Ancient Philosophy 49, pp.193-226. 
KonstAn, D. 1975, "A Note on Aristotle Physics 1.1". Archiv für Geschichte der Philosophie, n. 57, pp. 241-245.

Lesher, J. 2010. "Saphêneia in Aristotle: 'Clarity', 'Precision', and 'Knowledge'. Apeiron, 43 (4) pp. 143156.

Mansion, S. 1961. Aristote et les problèmes de méthode. Louvain: Publicacions Universitaires de Louvain. 1979. “'Plus connu en soi', 'plus connu pour nous'. Une distinction epistemologique importante chez Aristote." Pensamiento, v. 35, pp. 161-170.

MCKirahan, R. 1992. Principles and proofs. Princeton: Princeton U. P.

Minio-Paluello, L. 1949. Aristotelis Categoriae et Liber De Interpretatione. (Categ. and De Int.) Oxford: Clarendon Press.

Nussbaum, M. 1986. The fragility of goodness. Cambridge: Cambridge U. P.

Owen, G. E. L. 1961. "Tithenai ta phainomena". In S. Mansion (ed.), pp. 83-103.

Ross, W. D. 1908. Aristotle. Metaphysica. Oxford: Clarendon. 1924. Aristotle's Metaphysics. (Metaph.) Oxford: Clarendon. 1936. Aristotle's Physics. (Phys.) Oxford: Clarendon. 1949. Aristotle's Prior and Posterior Analytics (APr and APo) Oxford: Clarendon.

1955. Aristotle. Parva Naturalia. (PN) Oxford: Clarendon Press, 1955. 1956. Aristotle. De anima. (DA) Oxford: Clarendon. 
1958. Aristotelis Topica et Sophistici Elenchi. (Top. and Soph. El.) Oxford: Clarendon.

SHIELDS, C. 2013. "The Phainomenological Method in Aristotle's Metaphysics”. In E. Feser (ed.), pp. 7-27.

2016. Aristotle. De Anima. Oxford: Oxford University Press.

STOCKS, J. L. 1922. De Caelo. Oxford: Clarendon.

Walzer, R. R.; Mingay, J. M. 1991. Aristotelis Ethica Eudemia. (EE) Oxford: Clarendon.

$(\mathrm{Cc}) \mathrm{BY}$ 